\title{
The Impact of European Environmental Policies on Energy Prices. Possible Solutions in the Black Sea Region
}

\author{
Ioan-Cătălin Murărașu ${ }^{1}$
}

\begin{abstract}
Even if in Europe the costs of the transition to a green economy are reflected in the final consumer's bills and in the prices of finished products - an effect already felt in the Community - the necessity to clean up the economy cannot be disputed. However, Europeans need to determine if the priority is to give up conventional energy or to develop the green energy production, because it is becoming increasingly clear that the two objectives cannot be achieved simultaneously without affecting the purchasing power of Europeans. Within this context, the study involves: a) the statistical analysis of the impact of the conventional energy overtaxation and the renewable energy subsidization on the average price charged by suppliers for final consumers on the Romanian market in the first three quarters of 2021 and b) to identify the correlation coefficient between the spot price for energy on the Romanian market and the share of renewable energy in the national mix for the same period. The objective of the research is to assess the costs paid by the final consumers within the context of the energy transition and the production capacity of renewable sources that must be added to the National Energy System for their amortization. The results show the importance of the Black Sea basin in the regional energy equation and its potential to become a point of attraction for European energy investments.
\end{abstract}

Keywords: clean economy, conventional energy, green energy, over taxation, subsidization, Black Sea

JEL Classifications: H23, P18, Q41, Q50

DOI: $10.24818 / R E J / 2021 / 82 / 07$

\section{Introduction}

Regardless of nationality, political opinion, age or interests, the effects of climate change affect, in one way or another, every person on the planet. The increasingly acute, often catastrophic, effects on the environment and daily life have led to a real social revolt, having as enemies the great polluters and as an objective, driven by a global "thanatophobic" current, the fight against global warming. This possible revolution of public opinion manifested itself, especially in developed countries, where people have easy access to modern means of communication and

\footnotetext{
${ }^{1}$ Bucharest University of Economic Studies, Bucharest, Romania, catalin.murarasu96@gmail.com

Year XXIV no. 82 December 2021
} 
where the pro-environmental mentality has already been cultivated collectively. Even if concerns about long-term threats are more easily found in the minds of developed communities, compassion for nature and fear of apocalyptic scenarios have penetrated even less developed countries this time. Thus, South Americans protested after the fires in the Amazon, and Africans did the same in Nairobi, Cape Town, Kampala, Lagos (and not only) for world leaders to take action to combat climate change (Dahir, 2019).

After the industrial revolution, the negative effects of human activity on the environment have accumulated so that today it is reflected by the highest concentrations of carbon dioxide in the atmosphere in the last 2 million years and methane from the last 800 thousand years, $47 \%$ and $156 \%$ higher than 1750 , respectively (IPCC, 2021, p.9). The figures clearly show a strong need for change and leave no room for interpretations of the gravity of the situation or debates about a possible mythical dimension of the global warming process, its causes, or consequences. Doubled by a series of natural disasters unprecedented in modern history, which have led, in the last 20 years, to the loss of 500 thousand human lives and caused material damage worth 2.2 trillion Euros, statistical analysis of pollution determined by human activity unequivocally supports environmental policies, ratified, in particular, by the Paris Agreement (2015) and promoted in the contemporary public space (Eckstein et al., 2021).

All these realities make up a dark current context, which makes it impossible to validly argue a possible falsity of global warming, the clearest evidence being the declining number of opponents of global pollution reduction policies. The private sector also supports - with some reservations often caused by financial losses - the measures taken by world governments to combat climate change, this phenomenon often affecting even the businesses of major polluters (Bellanca and Wilson, 2012). Airlines are complaining about the turbulence generated by the warmer air at high altitudes, fuel manufacturers are finding it increasingly difficult to find employees willing to work in conditions that are harmful to health, and examples can continue. Under these conditions, both the public and private sectors are forced to reorient their activity and objectives, in line with the trend of transition to a sustainable economy, characterized, first and foremost, by a development disconnected from the impact on the environment and from consumption of primary resources (Regulation 2020/852 of the European Parliament and of the Council of 18 June 2020 on the establishment of a framework to facilitate sustainable investment).

The need of cleaning the economy cannot be disputed, but in the European Union, which has officially taken the lead in the fight against pollution, the costs of transitioning to a neutral economy are reflected in final consumers' energy bills 
and finished product prices. This is due not only to the fees charged by Member States for boosting the sustainable investments, but also to the forced closure of conventional production capacity, which has become unprofitable as polluting technologies fall into derision. The abandonment of fossil fuels is an essential condition for the neutrality that Europeans want in relation with the environment, but their premature abandonment - given that the capacity to produce energy from renewable sources would not be sufficiently supplemented - will reduce the market supply, the main effect being the increase of the price, but also of the imports from third countries. These effects could also be exacerbated by the increasing energy demand, as a result of encouraging other economic sectors, such as transport, to use the electricity.

The current evolution of energy market prices proves that Europeans need to determine whether the priority is to give up conventional energy or to increase the green energy production, and it is becoming increasingly clear that the two cannot be achieved simultaneously without price implications on a free market. Asthana (2021) argues that the energy sector is facing a "perfect storm", generated by rising prices for oil, gas and coal, which could throw the world into a new crisis in the next cold season. In the short term, solutions such as offsetting bills or overtaxing profits, already adopted by some European countries, could work, but in the medium and long term, the only option to maintain the leadership status and continue to be a role model for others in the fight against pollution is to increase production of green energy.

The purpose of this article is to identify the impact that the overtaxation of conventional energy, while encouraging the renewable energy had on the average price paid by the final consumers in Romania. To ensure the veracity of the results, the reference period will be limited to the first three quarters of 2021, when price volatility for the European Emission Trading System (EU ETS) was higher than in previous years, and the economic activity was similar to the one before the coronavirus pandemic. The analyzed electricity prices are published by the Romanian Commodities Exchange (brm.ro), and those for the EU ETS by the non-governmental organization Ember (ember-climate.org).

In order to demonstrate the thesis that the reduction of energy prices without diminishing the objectives assumed by the European Green Pact can be supported, in the long run, only by accelerating the process of developing production from renewable sources, the study will analyze the correlation between the market price and the share of renewable sources in the national energy mix, according to the information published by Transelectrica SA (the operator of the national electricity transmission system). The PSPPIRE program will be used to calculate the Pearson correlation coefficient between the mentioned variables. In

Year XXIV no. 82

December 2021 
the study were considered as part of the category of green energy types: hydropower, wind energy, photovoltaic and fuel based on biomass. Among the conventional (pollutants) production capacities were analyzed those based on coal, hydrocarbons, and nuclear fuel.

Although it can cover most of its consumption from domestic production, Romania is a net importer of electricity, especially in periods when renewable sources have low production rates caused by objective factors: climatic and meteorological conditions. In this context, the wind potential in the Black Sea region cannot be ignored. On the offshore perimeters of the entire region could be produced, theoretically, around $435 \mathrm{GW}$, of which at least $76 \mathrm{GW}$ in the Romanian area (World Bank Group, 2020). This hypothesis is also supported by Zaides (2000), who considers that the coastal areas near Constanta and Tulcea are some of the most favorable locations to place wind turbines. Thus, the offshore area controlled by Romania might become a point of attraction for foreign investments in the field of renewable energy production.

\section{Literature review}

The society's vision on energy production has faced major changes over the last 50 years. Until the end of the last century it was analyzed almost exclusively in terms of its profitability and rarely there was fathomed its impact on the environment. Thus, at the World Energy Conference in 1980, it was estimated a $20 \%$ increase in coal production by the year 2000 and there were even agreed investments for the development of this sector (Polach, 1981). Until the end of the last century, at the microeconomic level, energy issues were analyzed within companies exclusively in terms of costs reducing by consumption efficiency and resource management. Mashburn (1989) encourages the establishment of working groups, led by an energy manager, in each company for the purpose to identify solutions to optimize the costs incurred by private companies to ensure their energy needs. A similar point of view is currently supported by the Energy Efficiency Directive: Horizon 2030 (European Parliament, 2018), but the coverage area is much wider, with a $32.5 \%$ reduction in energy consumption in the Member States of the Union. European Union by 2030.

Hafele (1983) admits that renewable energy sources will develop by 2030 and their use will reach a level comparable to that of conventional sources but argues that their use involves two conditions: balancing energy systems with the conventional sources of energy and managing a redesign of the environment. The first condition deals with the instability of renewable sources and their dependence on climatic conditions and times of the day, and the second one concerns the impact

Year XXIV no. 82

December 2021 
on natural ecosystems of production capacities, in particular: hydropower, photovoltaics, and biomass fuel.

Vona and Nicolli (2014) argue that per capita incomes have the greatest impact on the willingness of Europeans to support the development of renewable energy sources, the second determining factor being the liberalization of the market. Thus, the process of increasing the share of green energy in the national mix is more easily agreed by the population of developed countries, which can more easily bear the costs imposed by this transition.

Although European environmental policy was adopted at the Paris European Council in 1972, the concrete steps to combat climate change have their origins in the Maastricht Treaty, which entered into force in 1993, which addresses environmental protection as a priority for the newly founded European Union. The same fundamental treaty grants a greater importance to the European Parliament and, implicitly, offers the possibility for the environmentalist parliamentary groups to promote their values in the Community's legislative steps (Jordan, 2005).

Even if the most European countries has liberalized their electricity market until 2008, respecting the Maastricht Treaty, which was the basis of several European directives and regulations, in Romania the liberalization was completed only on January $1^{\text {st }}, 2021$. Specifically, liberalization would mean that each customer, whether belonging to the category of domestic or non-domestic, would be able to choose a supplier and negotiate with him the conclusion of the contract for a tariff established based on the demand-supply ratio. In the European vision, the liberalization of the energy market would lead to lower prices by producers and suppliers and improved services for end customers (Volintiru et. al., 2019).

\section{Research methodology and results}

The price for electricity paid by the final consumers in Romania during the analyzed period consisted of the following elements:

Table 1. composition of the energy price in Romania

\begin{tabular}{|c|c|}
\hline Tariff for the used electricity & Variable (described in Figure 2$)$ \\
\hline Tariff for the transport & $0,01922 \mathrm{lei} / \mathrm{kWh}$ \\
\hline Tariff for the system services & $0,1082 \mathrm{lei} / \mathrm{kWh}$ \\
\hline Tariff for the distribution services & $0,15718 \mathrm{lei} / \mathrm{kWh}$ \\
\hline High efficiency cogeneration tax & $0,01712 \mathrm{lei} / \mathrm{kWh}$ \\
\hline The value of green certificates & $0,06407 \mathrm{le} / \mathrm{kWh}$ \\
\hline Excise & 0,523 lei $/ \mathrm{kWh}$ \\
\hline TVA & $19 \%$ of the final price \\
\hline
\end{tabular}

Source: Romanian Energy Regulatory Authority, 2021.

Year XXIV no. 82

December 2021 
In order to support European environmental policies in the field of energy, the structure of the price offered by suppliers for final consumers includes the value of green certificates $(0.06407 \mathrm{lei} / \mathrm{kWh}$ in the analyzed period), which aim to support, through subsidization, the production from renewable sources and the high efficiency cogeneration tax $(0,01712$ lei $/ \mathrm{kWh})$, used to streamline the existing production capacities, an objective assumed by the European Green Deal.

Figure 1. EU ETS - futures price (EUR/ton)

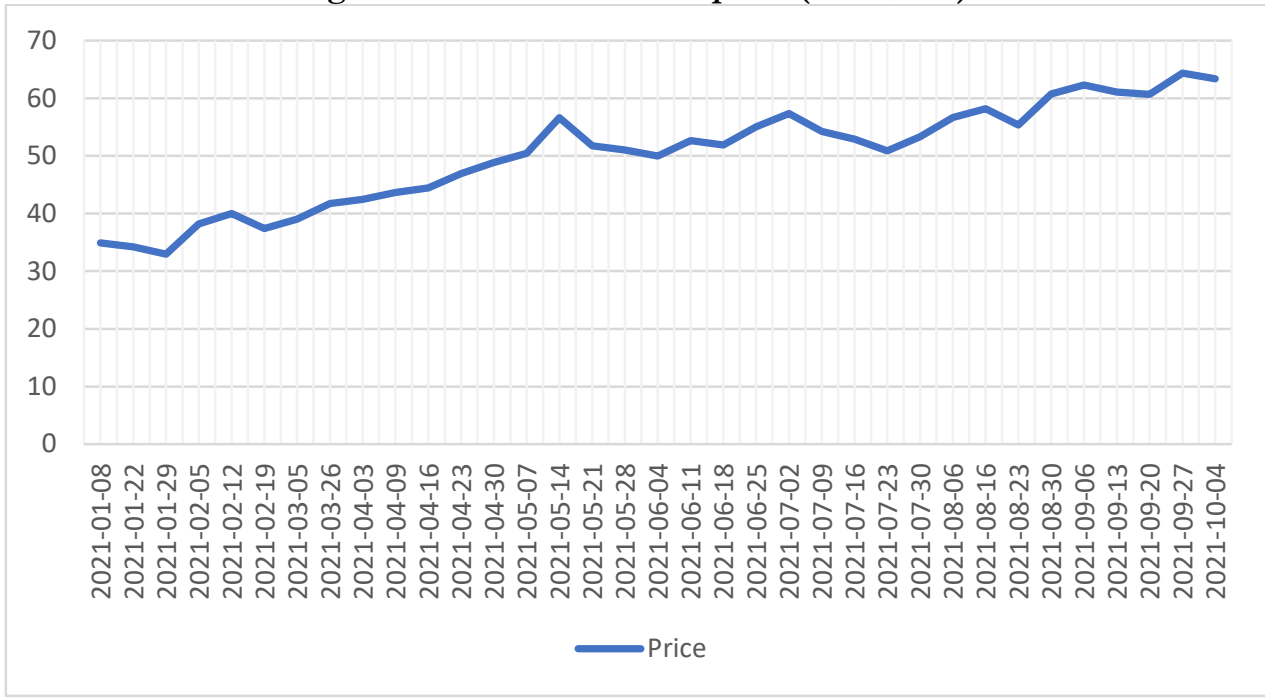

Figure 2. The electricity price (day and night) in Romania (lei/MWh)

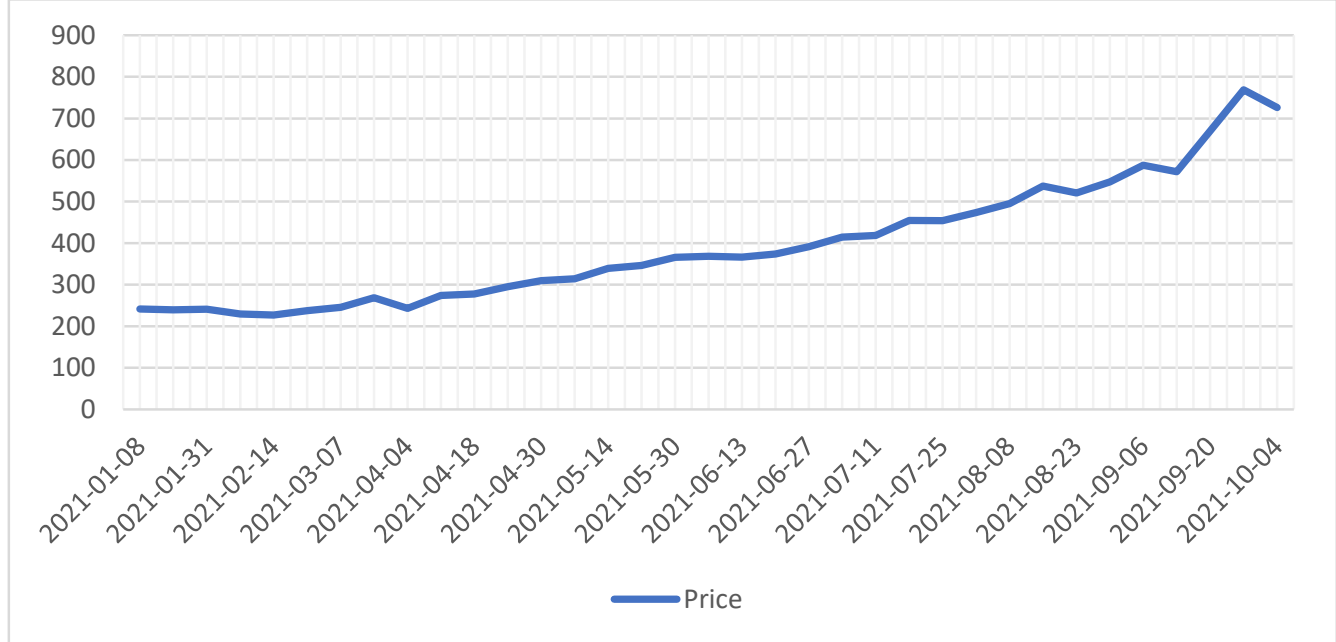

Year XXIV no. 82

December 2021 
Table 2. The Pearson correlation coefficient between EU ETS price and the price of energy in Romania

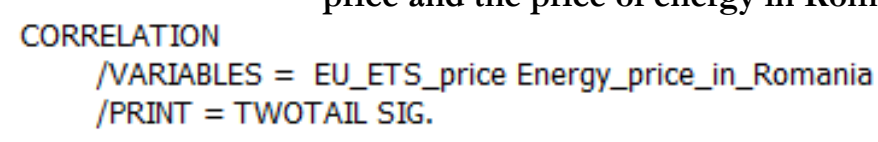

Correlations

\begin{tabular}{|ll|r|r|}
\hline & & EU_ETS_price & Energy_price_in_Romania \\
\hline EU_ETS_price & Pearson Correlation & 1.000 & .888 \\
& Sig. (2-tailed) & & .000 \\
& $\mathrm{~N}$ & 35 & 35 \\
\hline Energy_price_in_Romania & Pearson Correlation & .888 & 1.000 \\
& Sig. (2-tailed) & .000 & \\
& $\mathrm{~N}$ & 35 & 35 \\
\hline
\end{tabular}

There is a strong connection between the EU ETS price and the electricity price in Romania (Pearson correlation coefficient is 0.888 ). The costs generated by the purchase of greenhouse gas (GHG) emission certificates are reflected in the tariff for the electricity used. They are borne by the energy producing companies and further propagated in the selling price to the supplier. Therefore, in addition to the fixed values of green certificates and the high efficiency cogeneration tax (totaling 0.08119 lei $/ \mathrm{kWh}$ ), the value of the price charged for final consumers is also influenced by the value of GHG emission certificates.

Figure 3. The importance of the renewable energy (RE) in the national energy mix

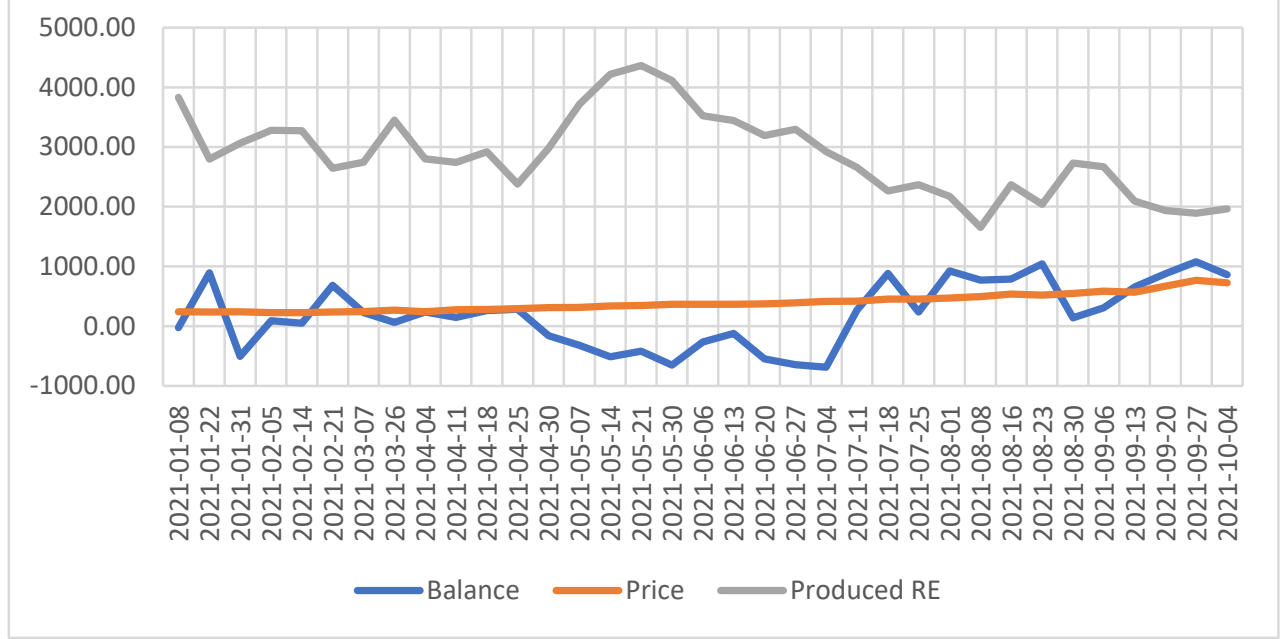


Table 3. The Pearson correlation coefficient between the production-consumption balance, the price of energy in Romania and the renewable energy produced CORRELATION

/VARIABLES $=$ Balance Energy_price_in_Romannia Produced_RE /PRINT = TWOTAIL SIG.

\begin{tabular}{|ll|r|r|r|}
\hline & Correlations \\
\hline Balance & Balance & Energy_price_in_Romannia & Produced_RE \\
& Pearson Correlation & 1.000 & .499 & -.817 \\
& Sig. (2-tailed) & & .002 & .000 \\
& $\mathrm{~N}$ & 35 & 35 & 35 \\
\hline Energy_price_in_Romannia & Pearson Correlation & .499 & 1.000 & -.602 \\
& Sig. (2-tailed) & .002 & & .000 \\
& $\mathrm{~N}$ & 35 & 35 & 35 \\
\hline Produced_RE & Pearson Correlation & -.817 & -.602 & 1.000 \\
& Sig. (2-tailed) & .000 & .000 & \\
& $\mathrm{~N}$ & 35 & 35 & 35 \\
\hline
\end{tabular}

The weak-moderate Pearson correlation coefficient between the balance (the difference between production and consumption) and the energy price in Romania shows that the energy deficit has an average impact on the price and not a high one, that would be specific to a liberalized market (example: oil market in 2020). This could indicate a high degree of interconnection of the national electricity network with those of the neighboring states and a good level of integration of the domestic market in the European/regional one.

On the other hand, the strong-negative Pearson correlation coefficient between energy production from renewable sources and the local deficit $(-0,817)$ shows the importance of these sources for the National Energy System, representing, in the analyzed period, on average, $45.9 \%$ of national production.

The moderate-negative Pearson correlation coefficient (0.602) between the price of electricity in Romania and the production of renewable energy shows, once again, the importance of these sources for the domestic market, increasing the production from these sources being a solution to reduce the prices. However, the link between the two variables can also lead to some risks, the instability of renewable sources and the dependence on climatic conditions favoring the volatility of the energy market.

\section{Conclusions}

The price of electricity in Romania is strongly influenced by the costs of environmental policies of the European Union. Thus, between the increase of prices for greenhouse gas emission certificates and that of energy tariffs characterized in the public space as an energy crisis - is a strong connection. The increase in prices for carbon certificates can be attributed, to a large extent, to the 
reduction of their number by $2.2 \%$ each year, starting with 2021, and the expiration (in 2020) of the period in which Romania could grant free certificates to the polluting companies (European Parliament, 2015).

Also, the Pearson correlation coefficient shows a link between the energy deficit on the market and the increase in prices, but a moderate one, due to Romania's possibility to import electricity at affordable prices from neighboring countries. The average deficit in the analyzed period was $167 \mathrm{MW}$, but more problematic than the inability to permanently cover domestic consumption is the volatility of production, currently combated with conventional, but stable, sources of energy (nuclear, coal and hydrocarbons). In the long run, these sources of production will become unprofitable due to the prices for emission allowances, and their use for balancing will become increasingly expensive.

Paradoxically, the only viable, long-term solution to combat this volatility is to increase the energy production from renewable sources. Their dependence on weather conditions and the calendar period causes fluctuations in national production, but green energy will become the only profitable one, as the costs of purchasing green certificates are going to increase. Therefore, in the context of the European policy to combat climate change, Romania must continue to invest in clean production capacities and in the interconnections of the national energy system with those of neighboring states, in order to import energy in times of deficit, reducing the national market volatility by its integration into the regional one.

Another solution, which will become economically inefficient with the tightening of European anti-pollution policies, is to balance the national energy system with the conventional energy sources, their production being controllable. Turning off these energy capacities, while the first solution presented is not fully implemented, will increase the volatility of production, exacerbate its deficit, and increase energy prices (Table 3). In addition, in order to balance the market, the transport operator will resort to imports from countries with energy excess. This situation would pose the risk that Romania would use energy produced with fossil fuels as well, but imported from countries outside the European Union, at higher prices. Under these conditions, the fight against pollution would become not only more expensive, but also a deceptive fight, with objectives ticked only on paper.

The strong negative link between the green energy production and the balance (Pearson correlation coefficient is $-0,817$ ) shows the importance of renewable energy in the national mix, but also its instability. In addition, it must be taken into account that most of the renewable energy is produced in Romania with the help of hydropower plants, on average 3.3 times more than the wind power, which is in 
second place. Hydropower production is stable (except during periods of drought), but investment in such capacity is costly and has a high impact on ecosystems. Therefore, wind energy - unstable, but much easier to obtain - will be preferred at the expense of hydropower.

The emplacement of the wind energy production capacities required favorable weather conditions (which prevent the formation of frost) and wind corridors with constant speeds, without strong gusts or periods of inactivity (Zaides, 2001). Romania has access to offshore perimeters in the Black Sea with wind speeds of $7.5-8.5 \mathrm{~m} / \mathrm{s}$, where it could develop viable wind farms with capacities up to 94GW, of which $22 \mathrm{GW}$ by installing fixed turbines (Bălan et al., 2020). The hypothesis is also supported by the World Bank Group, which estimates the wind energy production capacity on the Romanian Black Sea plateau at a minimum of $76 \mathrm{GW}$ and the total offshore technical potential in the Black Sea region at 435 GW. Under these conditions, Romania could have access to a true "energy lung" in Eastern Europe.

\section{References}

Asthana S., 2021. A perfect storm in the energy sector. Available at: https://www.moneycontrol. com/news/opinion/a-perfect-storm-in-theenergy-sector-7520081.html (Accessed 4 October 2021).

Bălan M., Dudău R., Cătuți M., Covatariu A., 2020. Romania’s offshore wind energy resources. București. Available at: https://www.enpg.ro/wpcontent/uploads/2020/11/EPG_Wind-Offshore-report_Final_Nov16.pdf.

Bellanca R., Wilson E., 2012. Sustainable energy for all and the private sector. Available at: https://www.osti.gov/etdeweb/servlets/purl/22031425 (Accessed 10 October 2021).

Dahir A. L., 2019. The climate economy. Available at: https://qz.com/ africa/1712980/ climate- strike- protests-in-africa-nairobi-cape-townlagos/ (Accessed 4 October 2021).

Directive (EU) 2018/2002 of the European Parliament and of the Council of 11 December 2018 amending Directive 2012/27/EU on energy efficiency. Available at: https://eur-lex.europa. eu/legal-content/EN/TXT/PDF/ ?uri=CELEX:32018L2002\&from=EN (Accessed 11 October 2021).

Directive 2015/148 of the European Parliament and of the Council amending Directive 2003/87/EC to enhance cost-effective emission reduction and low-carbon investments. Available at: https://eur-lex.europa.eu/legalcontent/EN/TXT/DOC/?uri=CELEX:52015PC0337R(01)\&fro $\mathrm{m}=\mathrm{SK}$ (Accessed 15 October 2021). 
Eckstein D., Künzel V., Schäfer L., 2021. Global climate risk index 2021. Who suffers most from extreme weather events? Weather-Related Loss Events in 2019 and 2000-2019. Available at: https://germanwatch.org/ sites/default/files/Global\%20Climate\%20Risk\%20Index\%202021_1.pdf (Accessed 6 October 2021).

Hafele W., 1983. Energy in a finite world. Roads to a viable future. Bucharest: Political Publishing House.

Intergovernmental Panel on Climate Change, 2021. Climate change 2021. The physical science basis. Summary for policymakers. Available at: https://www.ipcc.ch/report/ar6/wg1/downloads/ report/IPCC_AR6_WGI_SPM.pdf (Accessed 06 October 2021).

Jordan A., 2005. Environmental Policy in the European Union. Actors, institutions, and processes. London: Earthscan Publishing House.

Mashburn W.H., 1989. Managing energy resources in times of dynamic change. Lilburn: The Fairmont Press Publishing House.

Polach J. G., 1981. Coal-Bridge to the future and future coal prospects: country and regional assessments. National Resources Journal. No. 21.

Regulation (EU) 2020/852 of the European Parliament and of the Council of 18 June 2020 on the establishment of a framework to facilitate sustainable investment and amending Regulation (EU) 2019/2088. Available at: https://eur-lex.europa.eu/legalcontent/EN/TXT/HTML/?uri=CELEX:32020R0852\&from=en (Accessed 11 October 2021).

Volintiru C., Stoian M., Diaconu-Pințea L., 2019. The energy Operational concepts and tools. Bucharest: Club Romania Publishing House.

Vona F., Nicolli F., 2014. Energy market liberalization and renewable energy policies in OECD countries. Available at: https://www.sciencedirect.com /science/article/abs/pii/ S03014215193001 87 (Accessed 11 October 2021).

World Bank Group. 2020. Offshore wind technical potential in the Black Sea. Available at: https://documents1.worldbank.org/curated/en/ $718341586846771829 / \mathrm{pdf} /$ Technical-Potential-for-Offshore-Wind-inBlack-Sea-Map.pdf (Accessed 10 October 2021).

Zaides E. P, Zaides I. A, 2001. The energy conversion - technologies and resources. Bucharest: ICPE Publishing House. 